\title{
STUDIES ON INDIGENOUS ZEBU CATTLE. 1. REPRODUCTIVE PATTERN UNDER TRADITIONAL MANAGEMENT
}

\author{
H. ABEYGUNAWARDENA* and W.D. ABAYAWANSA \\ Department of Veterinary Clinical Studies, Faculty of Veterinary Medicine and \\ Animal Science, University of Peradeniya, Peradeniya.
}

\author{
(Received: 07 September 1994; Accepted: 11 August 1995)
}

\begin{abstract}
On-farm trials to determine the reproductive pattern, birth weight, growth rate, age at puberty, age at first calving, duration of postpartum anoestrus and gestation length of indigenous zebu cattle were conducted at three dry zone locations, namely Anamaduwa, Bandagiriya and Kandalama. Calving was seasonal with $66 \%$ calvings occurring during the months of October to January which coincided with North-East monsoon rains. The mean calving interval was $380.0 \pm 36.6$ days with majority of calving intervals ( $81 \%$ ) being less than 365 days. Mean birth weights of calves at Anamaduwa and Bandagiriya were $15.8 \pm 2.5 \mathrm{~kg}$ and $15.6 \pm 2.6 \mathrm{~kg}$ respectively. Average prepubertal growth rate of heifers was $107 \pm 208 \mathrm{~g}$ per day. Average ages at puberty at Anamaduwa, Bandagiriya and Kandalama were $845.1 \pm 138.8,870.9 \pm 92.8$ and $854.7 \pm 85.4$ days respectively. Average length of gestation was $281 \pm 5$ days. The ages at first calving at Anamaduwa and Kandalama were 1248.1 \pm 130.2 and 1172.5 \pm 57.4 days respectively. Postpartum involution of the uterus was completed by $24 \pm 5$ days. Lengths from calving to first elevation of plasma progesterone concentration in trial I and II at Anamaduwa were $41.7 \pm 39.3$ and $62.1 \pm 27.1$ days respectively, and the values for Bandagiriya and Kandalama, respectively were $94.5 \pm 16.6$ and $64.2 \pm 27.3$ days. Majority of animals conceived at the first postpartum oestrus. The length from calving to first elevation of plasma progesterone, calving to first observed oestrus and calving to conception intervals at Bandagiriya were greater $(p<0.05)$ than those at Anamaduwa and Kandalama. This may be due to free suckling by the calves at Bandagiriya as opposed to limited suckling practised at the other two locations. Results of this study suggest that indigenous zebu cattle under the dry zone management and environmental conditions reproduce at a high degree of efficiency following slow sexual maturity.
\end{abstract}

Key words: Cattle, zebu, puberty, oestrous cycle, gestation, calving pattern.

\section{INTRODUCTION}

Cattle indigenous to Sri Lanka are of Bos indicus type ("Zebu cattle") and hence called indigenous Zebu. They form the majority of the island's cattle population of 1.7 million $^{1}$ and are largely concentrated in the dry zone. They are managed extensively as large herds along with indigenous buffaloes with minimum inputs. ${ }^{2-4}$ This low-input operation brings modest income to the farmers, primarily from sale of milk and animals for meat. They appear to be well adapted to the marginal environmental conditions which prevail in the dry zone and form the basis of a very sustainable mixed crop-livestock agricultural production system.

\footnotetext{
" Corresponding author. Parts of this work were presented at the final research coordination meeting of the FAO/LAEA coordinated research programme on "strengthening research on animal reproduction and disease diagnosis in Asia through the application of immunoassay techniques", 1993, and the third annual congress of the Postgraduate Institute of Agriculture, University of Peradeniya, 1993.
} 
Indigenous cattle are characterized by small body size and stature and by relatively poor development of hump and dewlap as compared with most other tropical cattle. ${ }^{5}$ Although the origin of the native cattle in Sri Lanka is not certain, fragmentary evidence suggests that they may be the dependants of a primitive herd which at one time populated South Asia. Isolation in the island and absence of large scale importation of other types of cattle resulted in the perpetuation of these cattle in the country. ${ }^{6}$ Apart from very early reports ${ }^{6,7}$ the indigenous Zebu cattle have not been subjected to much scientific investigation.

The objective of this study was to determine the reproductive characteristics such as calving pattern, weight at birth, prepubertal growth rate, ages at puberty and first calving, gestation length and calving interval of the indigenous Zebu cattle maintained under the traditional dry zone management conditions.

\section{METHODS AND MATERIALS}

Locations: Three locations in the dry zone, viz. Anamaduwa,Bandagiriya and Kandalama were selected for the study. At all three locations, males and females were grazed together on communal lands and provided with night paddocks. The rainfall was seasonal at all three locations with precipitation ranging from 875 to $1875 \mathrm{~mm}$ per annum. Cows were milked once a day in the morning in the presence of the calf to provide a stimulus for milk let down. At Anamaduwa and Kandalama the calves were left behind in the paddock while the adults were taken for grazing, while at Bandagiriya they were sent with the adults to the grazing land and separated only in the evening.

Prepubertal Period: Birth weight measurements were obtained from calves from Anamaduwa $(n=33)$ and Bandagiriya $(n=17)$ using a weighing balance with a sensitivity of $0.5 \mathrm{~kg}$. Growth rate and age at puberty were studied in heifers aged 12-16 months at Anamaduwa $(n=10), 20-31$ months at Bandagiriya $(n=19)$ and 25-30 months at Kandalama $(n=15)$. Body weight was measured monthly using a weigh band. Blood samples for plasma progesterone assay were collected ten days apart every two months at Anamaduwa and ten days apart every month at Bandagiriya and Kandalama.

Postpartum period and gestation length: Cows were selected at calving from Anamaduwa (study I, $n=10$; study II, $n=12)$, Bandagiriya $(n=18)$, and Kandalama $(n=18)$. Their reproductive tracts were palpated rectally at seven days postcalving and blood samples were collected weekly until the next pregnancy was confirmed by palpation. Animals in study I at Anamaduwa were also palpated at weekly intervals from 7 days postpartum for ovarian size and structures, and changes in uterine size and position. At Anamaduwa 18 animals were monitored for duration of pregnancy by blood sampling at monthly intervals.

Calving pattern: At Anamaduwa, 15 farmers were instructed to record calving dates over 24 months. They were visited at monthly intervals to verify and collect the data. 
Blood Sampling: Blood samples were obtained by jugular venepuncture using heparinized vacutainers and were kept on ice until centrifugation at $3000 \mathrm{rpm}$ for ten min. Plasma was stored at $+5^{\circ} \mathrm{C}$ until transported to the laboratory where it was stored at $-20^{\circ} \mathrm{C}$ until assayed for plasma progesterone by radioimmunoassay (RIA).

Progesterone assay: Plasma was subjected to RIA using a solid-phase coated-tube method employing ${ }^{125}$ Iodine-progesterone as tracer (Joint FAO/IAEA Division of Nuclear Techniques in Agriculture, Vienna). The assay has previously been validated in our laboratory. ${ }^{8}$ The sensitivity of the assay was $0.1 \mathrm{ng} / \mathrm{ml}$ and the intra and inter-assay coefficients of variation were $9.7 \%$ and $13.7 \%$, respectively.

Statistical analysis: The estimates of various parameters were tested for differences among locations with Student's ' $t$ ' test and ANOVA.

\section{RESULTS}

Prepubertal Period: The mean birth weight, growth rate and age at puberty in each trial are given in Table 1 . The mean birth weights were $15.8 \pm 2.5 \mathrm{~kg}$ at Anamaduwa and $15.6 \pm 2.6 \mathrm{~kg}$ at Bandagiriya (no significant difference, $\mathrm{p}>0.05$ ). The average prepubertal growth rate of heifers was $107 \pm 208 \mathrm{~g} /$ day, with fluctuations related to the time of the year (Fig. 1). There was greater loss of weight during the months of August to October 1990, coinciding with a severe drought. The average body weight at first oestrus was $147 \pm 23 \mathrm{~kg}$.

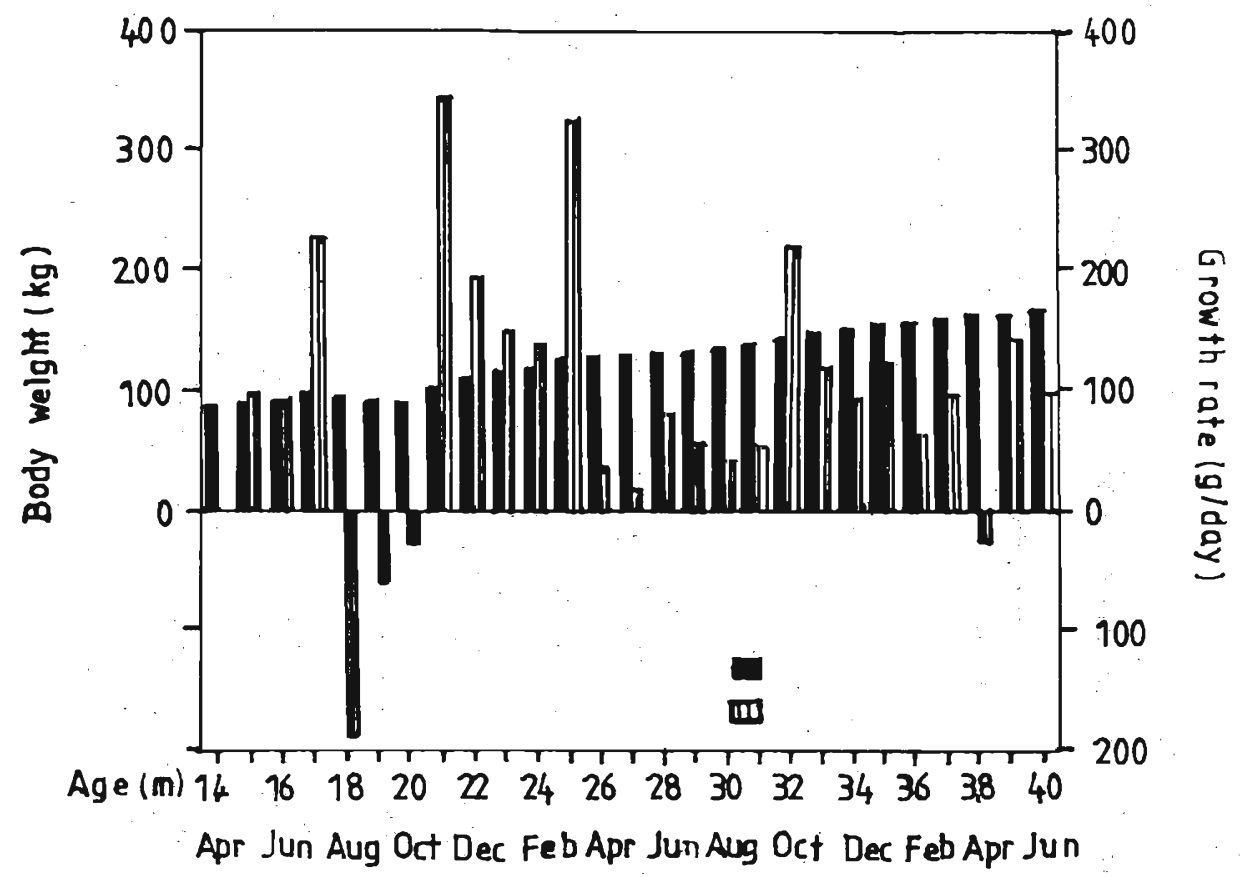

Figure 1: Body weights and growth rates during prepubertal period and around puberty of indigenous zebu heifers in the dry zone. 


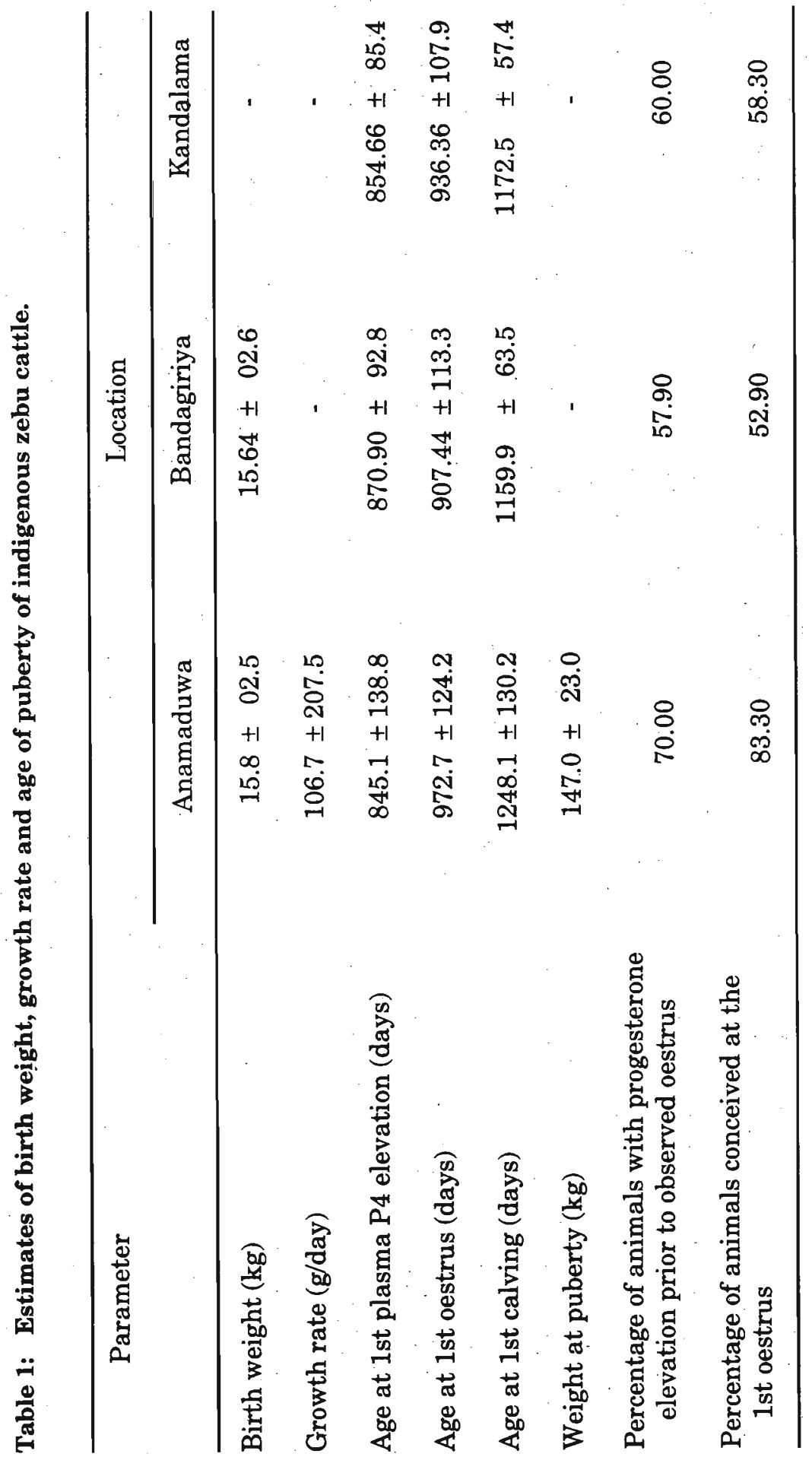


The average age at puberty, as determined by the first elevation of plasma progesterone with or without observed oestrus, at Anamaduwa, Bandagiriya and Kandalama were $845 \pm 138,870 \pm 93$ and $854 \pm 85$ days, respectively ( $p>0.05$ ). The ages at observed oestrus were $972 \pm 124,907 \pm 113$ and $936 \pm 108$ days, respectively for the three locations. Seventy percent of the animals at Anamaduwa, $58 \%$ of the animals at Bandagiriya and $60 \%$ of the animals at Kandalama showed short duration of elevated plasma progesterone concentrations prior to the observed oestrus periods. The age at first calving for Anamaduwa, Bandagiriya and Kandalama were $1248 \pm 130,1159 \pm 63$ and $1172 \pm 57$ days respectively.

Gestation Length: The average length of gestation was $281 \pm 5$ days with a range of 276 to 291 days. The mean plasma concentration of progesterone was $3.0 \pm 1.2$ $\mathrm{ng} / \mathrm{ml}$ during gestation.

Postpartum Period: The involution of the uterus was completed by $24 \pm 5$ days (range 18 to 34 ). The ovaries were very small and were estimated by palpation to be 10 to $15 \mathrm{~mm}$ long, 5 to $15 \mathrm{~mm}$ wide and 5 to $10 \mathrm{~mm}$ high. The follicular development was hardly detectable and the palpation of a corpus luteum was possible only in $62 \%$ of the cases where plasma progesterone was elevated.

Selected postpartum plasma progesterone profiles are shown in Figure 2. The intervals from parturition to first elevation of plasma progesterone, to first observed oestrus, and to conception are given Table 2 . In the majority of animals progesterone elevations were preceded by behavioural oestrus, and high proportion of animals conceived at the first oestrus. The intervals from calving to first elevation of progesterone, first observed oestrus and conception at Bandagiriya were greater than those at the other two locations $(p<0.05)$. The percentage of animals which remained anoestrus over a prolonged period was highest at Bandagiriya.

Calving pattern and Calving intervals: A total of 696 calvings were recorded. The majority of calvings (66\%) occurred during the months of October to January, with the peak in December (Figure 3 ). The calving season commenced with the onset of the North-East monsoon rains. The monthly frequency of calvings was correlated with the rainfall $(\mathrm{r}=0.85)$. The average calving interval was $338 \pm 36$ days with a range of 298 to 515 days $(n=254) ; 81 \%$ of calving intervals were less than 365 days.

\section{DISCUSSION}

This is the first study on characterising the reproductive functions of indigenous zebu animals in their traditional management systems. Previous studies have shown that zebu cattle form the base of the cattle farming in the dry zone. ${ }^{2,4}$ These animals are managed extensively as large herds on communal grazing lands with minimum inputs. 


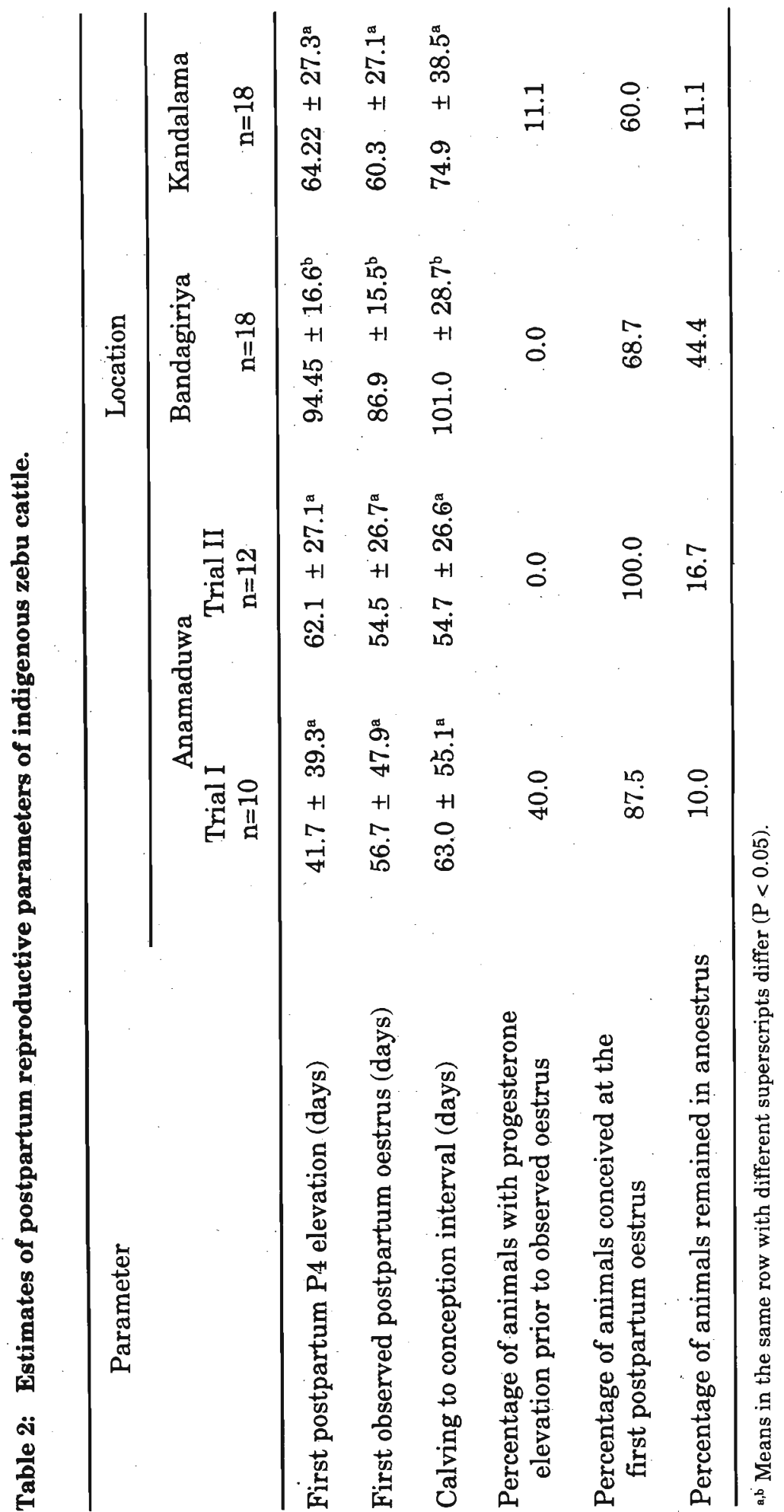



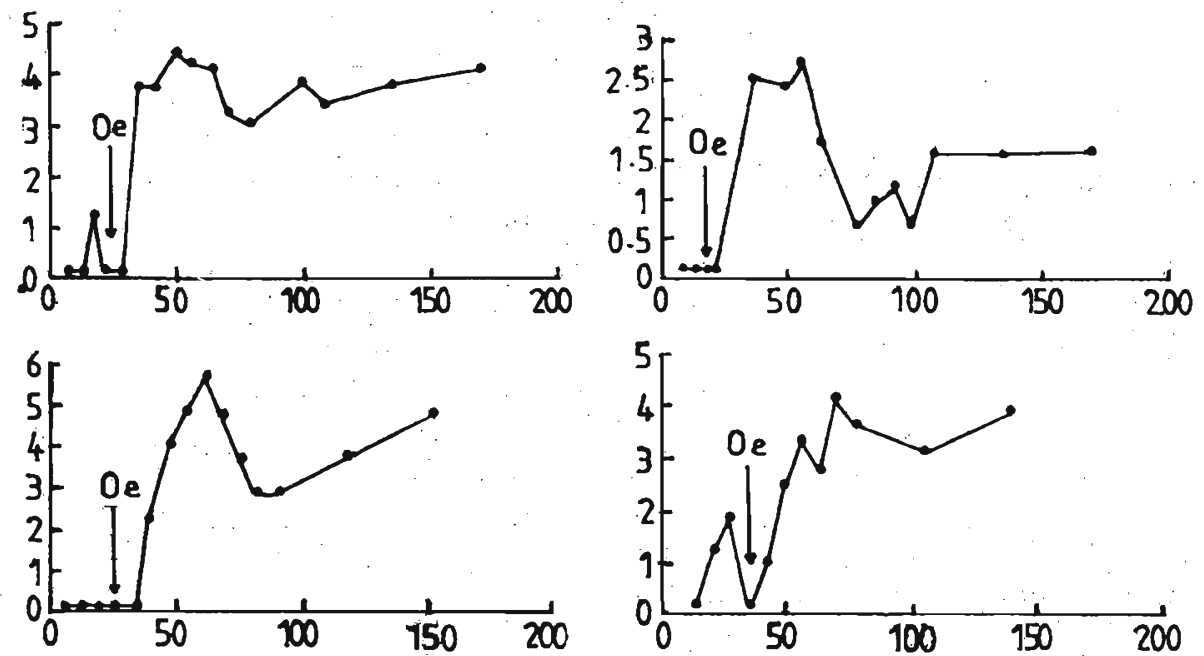

Figure 2: Selected plasma progesterone profiles in postpartum cows.

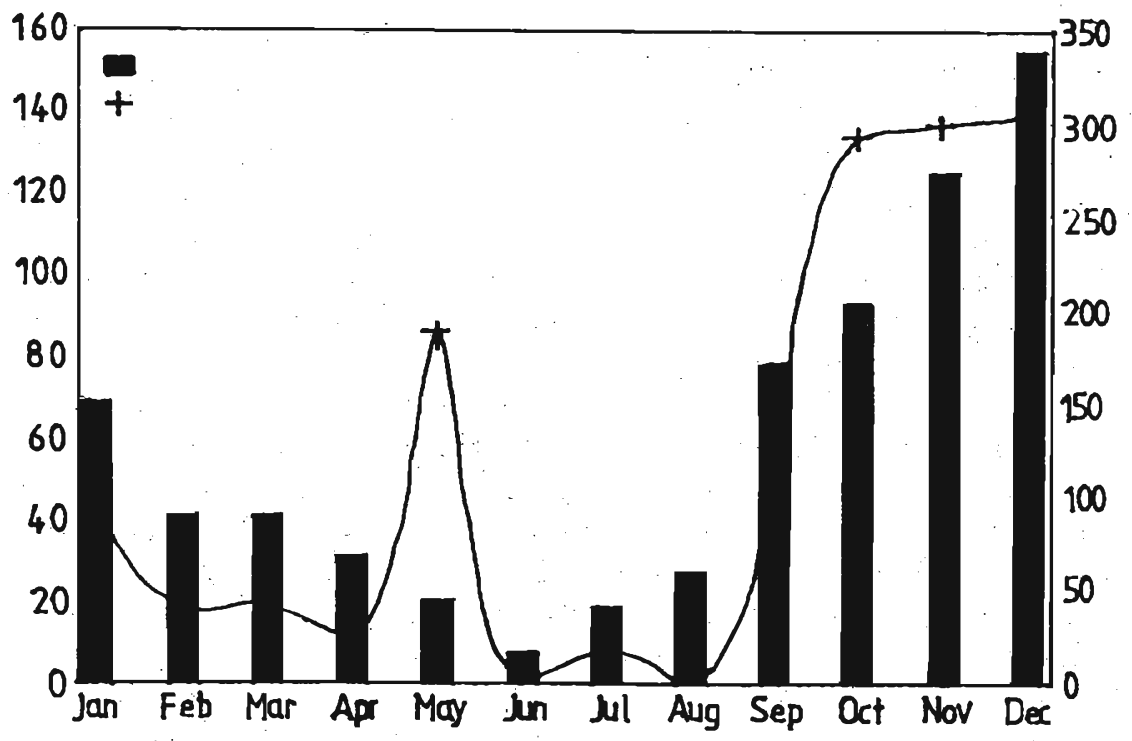

Figure 3: Calving pattern of indigenous zebu cattle in the dry zone. 
The body weight at birth was in agreement with the values reported for indigenous zebu maintained under experimental conditions. ${ }^{6}$. The prepubertal growth rate was very low, with fluctuations related to the time of the year. In comparison; birth weight and growth.rate performances of indigenous zebu are much lower than those of indigenous buffaloes. ${ }^{9}$ The lower birth weights may be due to continuous inbreeding of the animals in close localities over centuries. ${ }^{10}$ Further, this may have been due to poor nutrition of the mother during gestation, which often extends over into the drier months of the year. Another reason for this low average growth rate may be the wide fluctuations which occur due to adverse environmental conditions. In this study it was shown that the animals tend to lose weight during the drier months of the year, which usually extend from July to September. The negative effects of environmental stresses such as high ambient temperature and high relative humidity coupled with poor quality of herbage on prepubertal growth has been demonstrated. ${ }^{11}$

The age at which puberty occurred in animals in this study ranged from 22 to 36 months with an average of 32 months. These values were much higher compared to those reported for Bos taurus cattle but similar to many values estimated from age at first calving for many native breeds of cattle in Asia and Africa, and for Brahman cattle in arid zones of America. ${ }^{12}$ The delay in reaching puberty may be due to the low birth weight and slow growth rate during the prepubertal period; the latter could be due to a combination of low genetic potential for growth and poor nutrition during the major part of the year. Studies have shown that the age at puberty in Zebu cattle could be advanced by improving nutrition which also resulted in faster growth rates. ${ }^{13}$

The first oestrous cycle of many heifers was preceded by a short elevation of progesterone. This may be due to a short cycle prior to normal oestrus or due to luteinization of a preovulatory follicle before onset of regular oestrous cycles. Similar observations were noted by others in Bos taurus cattle. ${ }^{14}$ The majority of animals became pregnant at the first oestrous cycle. The age at first calving of indigenous animals was in close agreement with previous reports ${ }^{6}$ but higher than that reported in Bos taurus cattle. ${ }^{14}$ The gestation length of indigenous zebu cattle was similar to that of Bos taurus cattle ${ }^{12}$ but less than that reported for buffaloes. ${ }^{15}$

Calving interval of indigenous zebu cattle ranged from 298 to 515 days suggesting that fertility following calving is subjected to high variation: Further, cumulative relative frequency showed that about $81 \%$ of total calving intervals were within the range of 298 to 365 days. This variation is conceivably due to the effect of time of calving on the postpartum reproduction. In this study it was shown that the calvings were seasonal with the majority occurring during the North-East monsoon as also observed in indigenous ${ }^{9}$ and exotic buffaloes ${ }^{16}$ in Sri Lanka. These studies concluded that the seasonality of the calvings was due to entrainment of postpartum ovarian activity by seasonal availability of pasture and fodder which is governed by rainfall. Hence those animals which calve early in the calving season will resume oestrus activity postpartum earlier than the animals which calve late in the calving season. The latter usually experienced. 
prolonged postpartum anoestrus periods as they go into the drier months. The seasonal calving pattern and intercalving intervals were in agreement with the previous reports on indigenous cattle. ${ }^{2,6,7}$ The fact that a very high percentage of zebu cattle have intercalving intervals of less than one year suggests that their fertility following calving is very high contrary to the general belief. These short calving intervals are achieved despite the free suckling stimulus. The low milk production of these animals and their small body size may not demand a high plane of nutrition postpartum; this may be the reason for early return to oestrus following calving. The age at calving and calving interval have been shown to be dependent heavily on environmental and management factors since the heritability and repeatability of these traits are low. ${ }^{16}$

Uterine involution was completed within an average of 24 days postpartum; this is relatively shorter than reported in other types of cattle ${ }^{17,18}$ and buffaloes. ${ }^{19}$ Faster involution of the uterus could be due to its smaller size in indigenous Zebu cattle and the suckling stimulus provided by the young. The effect of milking and suckling on uterine involution has been shown to be due to more frequent and higher levels of oxytocin secretion. ${ }^{18}$

Ovaries of indigenous Zebu cattle were small and their dimensions were similar to those reported for indigenous buffaloes ${ }^{15,19}$ but were smaller than those of Bos taurus cattle. ${ }^{17}$ Due to the small ovaries, it was relatively difficult to assess follicular development rectally.

Postpartum ovarian activity, as measured by plasma progesterone concentration, commenced between 42 to 94 days in the majority of cows. In some animals, the first oestrus was followed by a short elevation of progesterone. A similar phenomenon has been reported in Bos indicus cattle elsewhere, ${ }^{20}$ Bos taurus cattle ${ }^{21}$ and in buffaloes. ${ }^{19}$ This could arise from a luteinized follicle ${ }^{21}$ or a short-lived corpus luteum. ${ }^{22}$ The cows at Anamaduwa and Kandalama resumed oestrus activity early in the postpartum period compared to those at Bandagiriya. Further, at Bandagiriya a higher percentage of animals remained in anoestrus over an extended period. The cows at Bandagiriya were subjected to ad-libitum suckling during the day time compared to those at Anamaduwa and Kandalama. Thus it is likely that the suckling stimulus and the cow-calf interaction in this group delayed the resumption of postpartum ovarian activity. This could prolong the calving to conception interval, as has been shown elsewhere in $\mathrm{Zebu}^{23}$ and taurine cattle. ${ }^{24}$ Despite the suckling stimulus the majority of animals resumed oestrous activity within 100 days postpartum and conceived at the first oestrus. This enables many cows to calve once a year. The high fertility found in this study is in agreement with the findings in other countries among native cattle of Bos indicus type. ${ }^{25}$

Tropical cattle and buffaloes in general have been considered as animals with variable calving intervals ranging from 12 to 24 months in many countries. ${ }^{25}$ This wide variation undoubtedly suggests that the reproductive function of the tropical Zebu cattle and buffaloes could be affected to a large extent by management and nutritional factors. This indeed has been demonstrated by 
numerous studies and the major determinants were suckling, poor nutrition and season of calving. ${ }^{12,25}$ The present findings corroborate previous conclusions that the interactions between genotype and environment are major determinants of the efficiency of reproduction.

It can therefore be concluded that the indigenous Zebu cattle of Sri Lanka, managed under the traditional rural dry zone system with minimum inputs for feed, labour and health care are able to reproduce with a high degree of efficiency following very slow sexual maturity. This high fertility of Zebu cattle under dry zone conditions appear to be the basis for a very sustainable cattle farming system in the dry zone. However, as the pressure on land increases, intensification will be inevitable and therefore further studies on minimizing suckling intensity and selection for traits with high heritability such as growth rate and milk yield may be very appropriate to optimize the milk and meat production from this valuable animal.

\section{Acknowledgements}

This study was sponsored by the International Atomic Energy Agency (SRL-5108/RB), the Natural Resources, Energy and Science Authority (RG/89/ V/03 and RG/92/V/01) and the University of Peradeniya (RG/10/C91/VT). The assistance given by the farmers, field enumerators and the technical assistants is greatly appreciated.

\section{References}

1. Sri Lanka Livestock Statistics (1986/87). Ministry of Rural Industrial Development, Sri Lanka.

2. Ozawa S., Buvanendran V., \& Gurusinghe R. (1978). Survey of production characteristics, feeding and management practices of cattle in some regions of the dry zone of Sri Lanka. Ceylon Veterinary Journal 26: 10-13.

3. Richards E.M. \& Agalawatte M. (1981). An inter-agro-ecological zone survey of cattle and buffalo management practices in Sri Lanka. FAO Report, CPC/SRL/30-SWE.

4. Abeygunawardena H., Jayatilaka M.W.A.P., Abayawansa W.D. \& Ratnayake D. (1991). Opportunities and limitations of cattle farming in the dry zone of Sri Lanka: evidence from a village case study. Sri Lanka Veterinary Journal 38: 26-27.

5. Mahadevan P. (1952). A study of the confirmation characteristics of Sinhala cattle. Tropical Agriculturist 58: 116-119.

6. Mahadevan P. (1952). The performance of the Sinhala cattle. Tropical Agriculturist 58: 253-237. 
7. Wijeratne W.V.S. (1970). Cross breeding Sinhala cattle with Jersey and Friesian in Ceylon. Animal Production 12: 473-483.

8. Abayawansa W.D., Abeygunawardena H. \& Jayatilaka M.W.A.P. (1991). Assessing the uterine involution and postpartum ovarian activity of indigenous zebu cattle in Sri Lanka. Tropical Agricultural Research 3: 266-275.

9. De Silva L.N.A., Perera B.M.A.O., Tilakaratne L. \& Edquvist L-E. (1985). Production systems and reproductive performance of indigenous buffaloes in SriLanka. Monograph, Swedish University of Agricultural Sciences; Uppsala, Sweden.

10. Sutherland T. M. \& Lush, J.L. (1961). Effects of inbreeding on size and type in Holstein-Friesian cattle. Journal of Dairy Science 45: 390-395.

11. Moran C., Quirke J.F \& Roche J.F. (1989). Puberty in heifers: a review. Animal Reproduction Science 18: 167-182.

12. Dobson H. \& Kamonapatana M. (1986) A review of female cattle reproduction with special reference to a comparison between buffaloes, cows and zebu. Journal of Reproduction and Fertility 77: 1-36.

13. Oyedipe C.E., Osori D.I.K., Akerejola O. \& Saror D. (1982). Effect of nutrition on onset of puberty and conception rates of zebu heifers. Theriogenology 18: 525-539.

14. Dobson S.E., McLeod B.J., Haresign W., Peters A.R. \& Lamming G.E. (1988). Endocrine changes from birth to puberty in the heifer. Journal of Reproduction and Fertility 82: 527-538.

15. Perera B.M.A.O., De Silva L.N.A., Karunaratne A.M. (1984). Studies on reproductive endocrinology and factors influencing fertility in dairy and draught buffaloes in Sri Lanka. In: The use of nuclear techniques to improve domestic buffalo production in Asia. International Atomic Energy Agency, Austria. pp 13-28.

16. Lundstrom K., Abeygunawardena H., De Silva L.N.A. \& Perera B.M.A.O. (1982). Environmental influence on calving interval and estimates of its repeatability in the Murrah buffalo in Sri Lanka. Animal Reproduction Science 5: 99-109.

17. Morrow D. A., Roberts S. J. \& McEntee K. (1969). A review of postpartum ovarian activity and involution of the uterus and cervix in cattle. Cornell Veterinarian 59: 134-154.

18. Wagner W. C. \& Oxenreider S.L. (1971). Endocrine physiology following parturition. Journal of Animal Science 32 (Supl.1): 1-16. 
19. Perera B.M.A.O., De Silva L.N.A., Kuruwita V.Y. \& Karunaratne A.M. (1987). Postpartum ovarian activity, uterine involution, and fertility in indigenous buffaloes at a selected village location in Sri Lanka. Animal Reproduction Science 14: 115-127.

20. Mukasa-Mugerwa E., Tegegne Azage and Ketema Hiskias. (1991). Pattern of postpartum oestrus onset and associated plasma progesterone profiles in Bos indicus cows in Ethiopia. Animal Reproduction Science 24: 73-84.

21. Webb R., Lamming G. E., Haynes N.B. \& Foxcroft G. R. (1980). Plasma progesterone and gonadotrophin concentration and ovarian activity in postpartum dairy cows. Journal of Reproduction and Fertility 59: 1'13-143.

22. Madej A., Kindahl H., Larsson K. \& Edqvist L-E. (1986). Sequential hormonal changes in the postpartum dairy cow. Acta Veterinaria Scandinavia 27:280295.

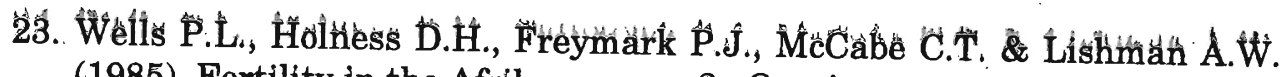
(1985). Fertility in the Afrikaner cow. 2. Ovarian recovery and conoeption in suckled and non-suckled cows postpartum. Animal Reproduction Science
8: $315-326$.

24. Carruthers T.D. \& Hafs H.D. (1980). Suckling and four times daily milking, influence on ovulation, oestrous and serum luteinizing hormone, glucocorticoids and prolactin in postpartum Holsteins. Journal of Animal Science 50: 919925.

25. Galina C. S. \& Arther G. H. (1989): Review of cattle reproduction in the tropics. Part 2. Parturition and calving intervals. Animal Breeding Abstracts 8: 679-
686. 